EJEM

Econ.J.Emerg.Mark.

\section{Economic Journal of Emerging Markets}

Available athttp://journal.uii.ac.id/index.php/jep

\title{
Meat demand model in Iran: a restricted source-differentiated almost ideal demand system approach
}

\author{
Elham Pourmokhtar ${ }^{0}$, Reza Moghaddasi ${ }^{\left[0^{*}\right.}$, Amir Mohammad Nejad, \\ Seyed Safdar Hosseini
}

Department of Agricultural Economics, Faculty of Agriculture and Natural Resources, Islamic Azad University, Science and Research Branch, Tehran, Iran

Corresponding author e-mail: $\underline{\text { r.moghaddasi@srbiau.ac.ir }}$

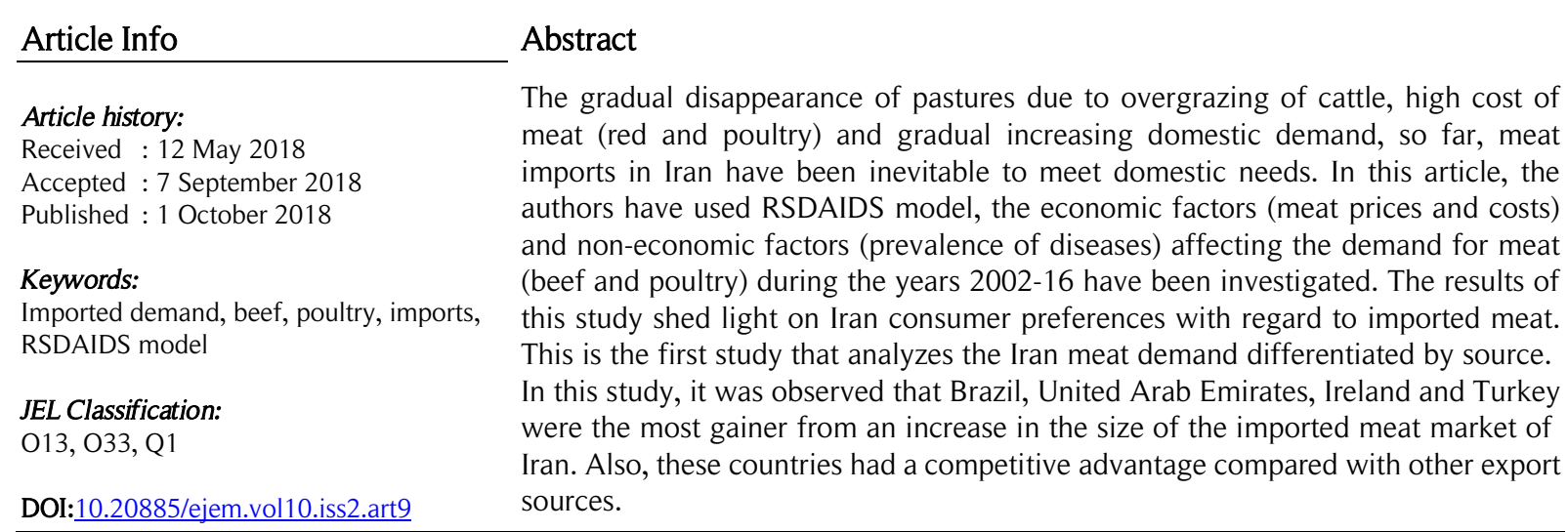

\section{Introduction}

Iran is the second largest country in the Middle East with a population of nearly 80 million people. After Egypt, Iran is regarded as the second largest consuming market in the Middle East followed by North Africa with approximately 80 million consumers. Over past 20 years, the Iranian agricultural sector accounts for the smallest portion of the GDP (Gross Domestic Product) with only 8.3\%. On an average, the agronomy sector accounts for $65.7 \%$ of the value added of the Iranian agricultural sector, followed by animal husbandry and hunting, fishing, agricultural services and forestry with 26.8, 4.4, 2.6 and 0.5\%, respectively (Anonymous, 2017).

According to the reports released during 2018 by the Iranian Center for Strategic Research, the production of beef, mutton and poultry has reached 2.673 million tonnes in 2017 (with a growth rate of $0.8 \%$ in comparison to the previous year). An important part of meat production in Iran is allocated for poultry production; 2.172 million tonnes of poultry have been produced in 2017 (with a growth rate of $0.5 \%$ in comparison to the previous year). In 2017, the per capita meat (including both beef and mutton) and poultry consumption has been reported to 26 and $12 \mathrm{~kg}$, respectively.

The per capita meat consumption of each of the members of a four-member family in low-income group families [the monthly income of less than 20 million Iranian Rial (about 40 Euro) per month] as well as average and high-income group families (the monthly income of more than 20 million Iranian Rial per month) is 11 and $38 \mathrm{~kg}$, respectively. These statistics indicate the elasticity of high incomes for meat demand. The studies conducted by the researchers indicate that instead of consuming red meat, the consumers start consuming alternative meat (poultry) when their incomes decrease, and in low-income levels, red meat has turned out to be a luxury product.

According to the statistics released during 2017 by the Ministry of Agriculture, Jihad, the red meat production has not significantly increased over the past two years (2015-17). In the past, only 10\% of the country's need for red meat was fulfilled through imports. However, this percentage has significantly changed over the past two years; the imports have increased to more than $40 \%$. The conditions ruling the red meat market as well as the relative increase of this product in recent years in Iran are resulted from reduced tariffs on imports, policy makers' inattention to domestic producers, domestic producers' problems including drought and animal feed scarcity. As a result, the domestic red meat producers are thus dealing with numerous problems. The domestic producers are thus forced to send most of the highly productive animals to slaughterhouses; the 
productive livestock population (especially light livestock) has thus decreased. Despite the country's high capacity for red meat production, most of the light livestock producers have lost the market to carcass importers.

About poultry trade, fact is that as much as $25-30 \%$ of the global poultry trade is being conducted with neighboring Iran countries (about 6 billion dollars). However, Iran does not have a significant share in poultry exports. The poultry exports of Iran have been around 25,000 tones over the past 20 years; this accounts for only $1.6 \%$ of the region's total exports. These studies show that most of the chicken feeds are imported, resulting in a higher price for chicken feeds. The increased price of chicken feeds (about 70\%) as well as the increased cost of buying one-day old chicks (about 16\%) resulted in an increased end price of poultry. At present, it seems difficult to import poultry in the large scale and to compete with other countries. In this regard, it can be stated that in terms of red meat and poultry exports, Iran is a relatively small country. However, as for the foreign trade of red meat and poultry, Iran is a relatively significant country. Thus, the necessity of fulfilling self-sufficiency in agricultural sector, especially self-sufficiency in producing different kinds of meat has led the policy makers towards recognizing the factors affecting the imports and production of red meat and poultry through analyzing the efficiency of the existing methods of supplying and marketing of these products (Parizan and Esmaeili, 2008).

Therefore, the main objectives of this study are to evaluate the effects of economic factors (meat prices and costs) as well as non-economic factors (animal disease outbreaks) on meat request from various sources in Iran. Thus, accessing meat competition from various sources seems possible in the Iranian meat market. The findings of this study certainly will help to adopt strategic decisions about the Iranian consumers' behaviours in the consumption of meat products. Numerous studies have estimated import demand function consistent with economic theory. The AIDS model of Deaton and Muellbauer (1980) is one of the most popular models for analyzing the import demand function. In several cases, the use of restricted source differentiated AIDS (RSDAIDS) specification to estimate the import demand has been reviewed. A number of studies have used the restricted source differentiated AIDS (RSDAIDS) specification to estimate of import demand, including those conducted by Boumahdi et al. (2004), Henneberry and Seong-huyk (2007), Mekonnen et al. (2011), Thanagopal and Felix (2014), Cheng et al. (2015), Capitello et al. (2015), Gómez et al. (2015) and Sun and Niquidet (2017).

\section{Research Methods}

\section{Empirical specification of the RSAIDS model}

The almost ideal demand system (AIDS) was used in this study. This model has been one of the most popular research tools in applied demand analysis. The RSDAIDS imposes block substitutability, which assumes that the cross-price effect of products in good 'j' on the demand for product ' $h$ ' in good ' $i$ ', are the same for all products in good 'j' (Yang and Koo, 1994). Following Yang and Koo (1994), the RSDAIDS is specified as under:

$$
w_{i h}=\alpha_{i h}+\sum_{k} \gamma_{i h k} \ln \left(P_{i k}\right)+\sum_{j \neq i} \gamma_{i h j} \ln \left(P_{j}\right)+\beta_{i h} \ln \left(\frac{M}{P^{*}}\right)
$$

Where, subscripts ' $\mathrm{i}$ ' and ' $\mathrm{j}$ ' indicate goods $(\mathrm{i}, \mathrm{j}=1,2, \ldots \mathrm{N})$, and ' $\mathrm{h}$ ' and ' $\mathrm{k}$ ' indicate supply sources, $w_{\text {ih }}$ is the budget share of good ' $\mathrm{i}$ ' from source ' $\mathrm{h}$ ', $\alpha_{i h}$ is an intercept term for meat ' $\mathrm{i}$ ' from source $\gamma_{i h k}$ is the price coefficient of source differentiated good $P_{i k}$ is the price of good ' $\mathrm{i}$ ' from source ' $\mathrm{k}$ ' (with k including h), $\gamma_{i h j}$ is the cross-price coefficient between source differentiated good ' $i$ ' from source ' $h$ ' and no source differentiated, $\beta$ is the real expenditure coefficient, $\mathrm{E}$ is group expenditures, $P_{j}$ is the price of the no source differentiated good ' $\mathrm{j}$ ' and was calculated as the weighted average of source differentiated ' $\mathrm{j}$ ' prices as follows:

$\ln \left(P_{j}\right)=\sum_{k} w_{j k, t-1} \ln \left(P_{j k}\right)$

$P^{*}$ is a price index which for source differentiated AIDS is defined as under:

$\ln \left(P^{*}\right)=\alpha_{0}+\sum_{j} \sum_{h} \alpha_{j h} \ln \left(P_{j h}\right)+\frac{1}{2} \sum_{i} \sum_{j} \sum_{h} \sum_{k} \gamma_{i h j k}^{*} \ln \left(P_{i h}\right) \ln \left(P_{j k}\right)$

The RSDAIDS model in above equation 1 is nonlinear due to the nonlinear price index in equation 3 . To make the system linear, Deaton and Muellbauer (1980) suggest using Stone's price index, here specified as follows:

$\ln \left(P^{*}\right)=\sum_{i} \sum_{h} W_{i h} \ln \left(P_{i h}\right)$

The budget shares $W_{i n}$ that are used as dependent variables in equation 1, are also used as independent variables in the aggregate price calculation in equation 4. Therefore, to avoid simultaneity bias following Eales and Unnevehr (1988), this study uses lagged budget shares $w_{j k, t-1}$ to compute Stone's price index. Therefore, in this study, the intercept term in equation 1 is defined as follows: 
$\alpha_{i h}=\alpha_{i h 0}+\sum_{g=1}^{G} \alpha_{i n g} D_{G}$

Following Yang and Koo (1994), homogeneity and symmetry are imposed as shown in following equations 6 and 7, respectively, where D represents the three indicator variables (BSE, FMD) and Avian Influenza (Flu) outbreaks exporter countries are included.

$$
\begin{aligned}
& \sum_{k} \gamma_{i h k}+\sum_{j \neq i} \gamma_{i h j}=0 \\
& { }_{i h k}=\gamma_{i k h}, \forall i, h, k
\end{aligned}
$$

Due to the inclusion of indicator variables in the RSDAIDS model in equation 1, the adding-up property of demand is imposed as follows:

$\sum_{i} \sum_{h} \alpha_{i h o}=1, \quad \sum_{i} \sum_{h} \alpha_{i h g}=0 \quad \forall i, \sum_{h} \gamma_{i h k}=0, \quad \sum_{i} \sum_{h} \beta_{i h}=0, \sum_{i} \sum_{h} \gamma_{i h j}=0 \quad \forall i, h$

Block substitutability makes the symmetry conditions among goods not applicable (Yang and Koo, 1994). The condition of block separability among goods proposed by Hayes et al. (1990) was verified by testing whether:

$\gamma_{i k j}=w_{i h} \cdot w_{j k} \cdot \gamma_{i j} \quad \forall j \neq i$

Where, $\gamma_{i j}$ is the cross-price parameter between groups $i$ and $\mathrm{j}$, estimated from an aggregate AIDS model. The hypothesis of product aggregation, considering the block substitutability was imposed by testing the following assumptions:

$\alpha_{i h}=\alpha_{i} \quad \forall h \epsilon i ;, \gamma_{i h j}=\gamma_{i j} \quad \forall h, k \epsilon i, j, \beta_{i h}=\beta_{i} \quad \forall h \epsilon$

The hypothesis is that the country of origin affects the preferences of consumers.

Block separability test

This model assumes, however, that while allocating expenditures among different sources of the same good, consumers do not distinguish among sources of other goods (Hayes et al., 1990). Block separability is tested for using the Wald F-test (Andayani and Tilley, 1997).

Marshallian (uncompensated), Hicksian elasticities (compensated) and expenditure elasticity

The estimated parameters of the RSDAIDS model were used to compute the Marshallian and Hicksian ownprice and cross-price demand elasticities and the expenditure elasticity (Green and Alston, 1990). The Marshallian (uncompensated) elasticities, Hicksian elasticities (compensated) and expenditure elasticity are presented in Table 1.

\section{Estimation procedures and statistical tests}

Since both the time series vertical data and the cross-sectional horizontal data are joined, panel data have the advantage of a large observation sample. Panel data models are usually estimated using either fixed or random effect techniques. The basic idea is to start with following equation 11 (Giorgioni and Holden, 2003):

$Y_{i t}=\beta_{1}+\beta_{2 i} X_{2 i}+\beta_{3 i} X_{3 i}+u_{i}$

In this model, authors assume that it is a random variable with a mean value of $\beta_{1}$ (no subscript ' $i$ ' here) and the intercept value for individuals can be expressed as under:

$\beta_{1 i}=\beta_{1}+\varepsilon_{i} \quad i=1,2, \ldots, N$

Where,

$$
\begin{gathered}
\varepsilon_{i} \sim \widetilde{N}\left(0, \sigma_{\varepsilon}^{2}\right), \quad u_{i t} \sim \widetilde{N}\left(0, \sigma_{u}^{2}\right), \quad E\left(\varepsilon_{i} u_{i t}\right)=0, \quad E\left(\varepsilon_{i} \varepsilon_{j}\right)=0 \quad(i \neq j) \\
E\left(u_{i t} u_{i s}\right)=E\left(u_{i t} u_{j t}\right)=E\left(u_{i t} u_{j s}\right)=0, \quad(i \neq j, \quad t \neq s)
\end{gathered}
$$

Hausman and Taylor (1981) provide a test for discriminating between the estimators of fixed and random effects. Consider the following set of equations:

$y_{i}=\beta_{i} X_{i}+u_{i} \quad$ for $\quad i \in\{1, \ldots, m\}$ 
Where, the index ' $i$ ' denotes the i-th equation in the considered system (Breusch and Pagan, 1980). Levin et al. (2002) showed that using a unit root test for panel data has a higher test power in comparison to a unit root test for each section is coexistent.

\section{Data and sources}

This study uses secondary data collected from various sources. These data consist of the volume (in thousand tonnes) and values of imported sources viz. beef and poultry (in US dollars) for the period from 2002-16, obtained from United Nations Commodity Trade Statistics Database and the Tehran Chamber of Commerce Industries Mine and Agriculture. Import values include cost, insurance and freight (CIF).

Real price $=$ Nominal price $\times($ Base period $\mathrm{CPI}) /($ Nominal period $\mathrm{CPI})$

Real price $=$ Nominal price $\times \frac{\text { Base period } C P I}{\text { Nominal Period } C P I}$

$E_{\text {Countries }}=\sum_{i=i}^{n} E_{i} \Rightarrow W_{i}=\frac{E_{i}}{E_{\text {Country }}} \Rightarrow P_{\text {country }}=\sum_{i=1}^{n} w_{i} p_{i}$

The sample statistics of expenditure shares for each product is summarized in Table 1. Among two meat items, the larger import accounts on the average for beef nearly $44 \%$ followed by poultry (67\%). A country was identified as an import origin if it exported in terms of values over $5 \%$ for each meat category. Import sources that took less than $5 \%$ were combined into a single country named "Rest of World" for each meat category. During the years 2002-16, the main countries exporting beef to the Iranian market were Brazil, United Arab Emirates, Ireland and Netherlands. Poultry was imported mainly from Brazil, United Arab Emirates and Turkey. In rest of world, major countries for beef import included Australia, Belgium, India and Germany and, for poultry include Republic of Korea, Germany, Ukraine, China and Portugal. Regarding the trend of beef import (Fig. 1) from Brazil to Iran between 2009 and 2013 indicated its downside. According to the OIE report, due to the spread of Foot and Mouth Disease (FMD) between 2012-08 several beef importing countries initiated an import ban. The maximum reduction in imports from Brazil in 2013 was due to an outbreak of BSE in addition to FMD (Fig. 1).

\section{Beef}

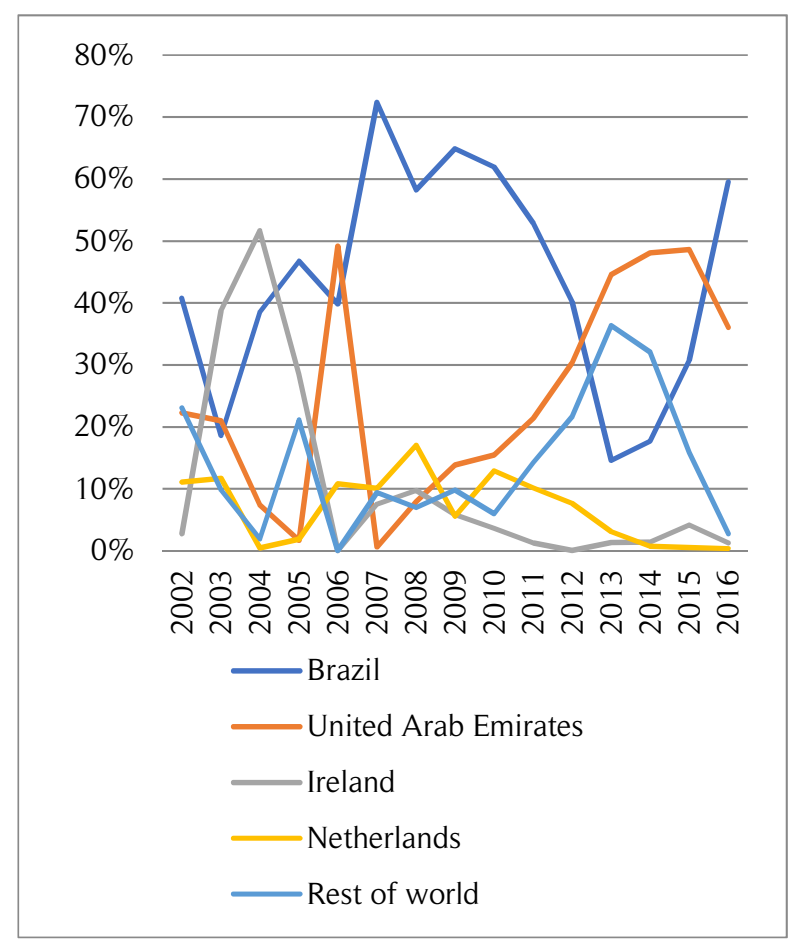

Poultry

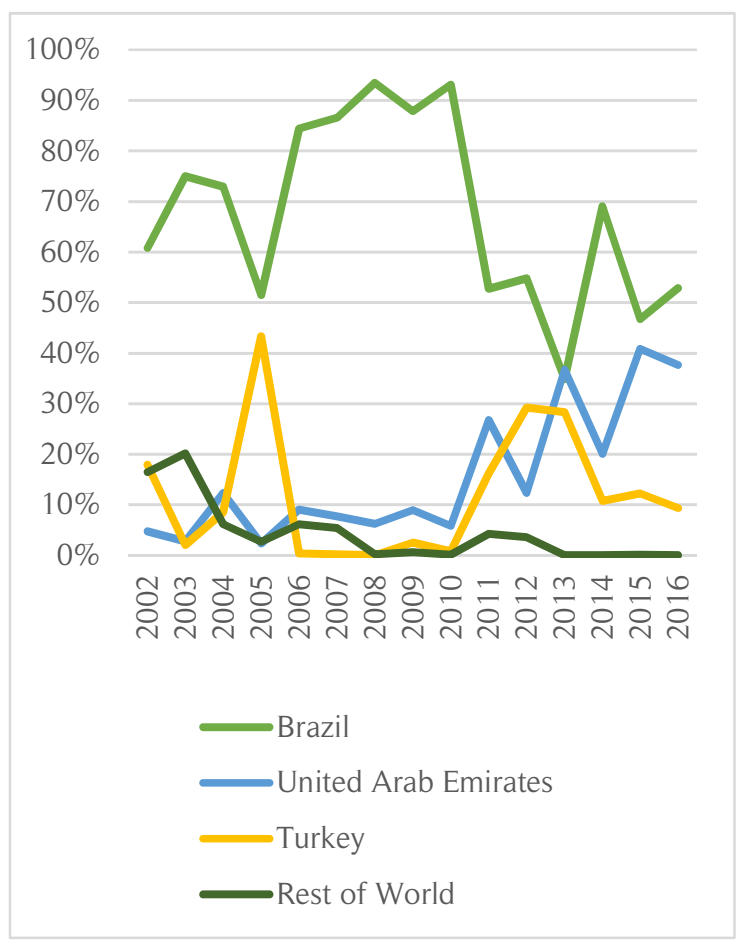

Figure 1. Evolution of beef and poultry import shares from 2002 to 2016 


\section{Results and Discussion}

\section{Parameter estimates}

Source-differentiated models allow us to separate sources that are important for policy-related research, and the modification of the Yang and Koo block-substitutability restrictions enables us to estimate large models with relatively limited data sets. The STATA12 program was used to estimate nine equations by the SUR method with the homogeneity, symmetry and block substitutability conditions imposed. Each equation includes seven parameters, with diseases dummy variable and intercept variable. Degrees of freedom are not a problem since the data set has a total of 135 observations. The results of the SUR system are shown in Table 1.

Table1. Marshallian elasticities, Hicksian elasticities and expenditure elasticity

\begin{tabular}{lcc}
\hline \multicolumn{1}{c}{ Kind of elasticity } & Marshallian elasticities & Hicksian elasticities \\
\hline Own-price elasticity of good i from source $\mathrm{h}$ & $\varepsilon_{i h i h}=-1+\frac{\gamma_{i h h}}{W_{i h}}-\beta_{i h}$ & $\varepsilon_{i h i h}=-1+\frac{\gamma_{i h h}}{W_{i h}}-W_{i h}$ \\
$\begin{array}{l}\text { Cross-price elasticity of good i from different } \\
\text { sources (with } \mathrm{k} \neq \mathrm{h} \text { ) }\end{array}$ & $\varepsilon_{i h i k}=-1+\frac{\gamma_{i h k}}{W_{i h}}-\beta_{i h} \frac{W_{j k}}{W_{i h}}$ & $\varepsilon_{i h i k}=\frac{\gamma_{i h k}}{W_{i h}}+W_{i k}$ \\
$\begin{array}{l}\text { Cross-price elasticity of good i with a different } \\
\text { good } \mathrm{j} \text { (with } \mathrm{j} \neq \mathrm{i} \text { ) }\end{array}$ & $\varepsilon_{i h j}=-1+\frac{\gamma_{i h j}}{W_{i h}}-\beta_{i h} \frac{W_{j}}{W_{i h}}$ & $\varepsilon_{i h j}=\frac{\gamma_{i h j}}{W_{i h}}+W_{j}$ \\
Expenditure elasticity & $\eta_{i h}=\frac{\beta_{i h}}{W_{i h}}+1$
\end{tabular}

Moschini (1995) and Chern et al. (2003).

Tables 2, 3 and 4 also presents the parameter estimates and associated t-ratio of the expenditure share function systems from RSDAIDS. For the beef share equation, the expenditure coefficients were significant and negative for Brazil and ROW. This implies that the beef expenditure share of Brazil and ROW would decrease, with any increase in the real total expenditure, but the beef expenditure share of United Arab Emirates, Ireland and the Netherlands would increase.

Table 2. Summary statistics for expenditure shares for Iran meat imports (2002-16)

\begin{tabular}{lllll}
\hline Variable & Mean & Std. Dev. & Min & Max \\
\hline Beef & & & & \\
\hline Brazil & 0.4384 & 0.1800 & 0.1459 & 0.7237 \\
United Arab Emirates & 0.2457 & 0.1731 & 0.0062 & 0.2142 \\
Ireland & 0.1055 & 0.1593 & 0.0004 & 0.5167 \\
Netherlands & 0.0696 & 0.5480 & 0.0040 & 0.1706 \\
Rest of world (ROW) & 0.1408 & 0.1088 & 0.0006 & 0.3637 \\
\hline Poultry & & & & 0.935 \\
\hline Brazil & 0.6779 & 0.1866 & 0.3486 & 0.4089 \\
United Arab Emirates & 0.1564 & 0.1344 & 0.0236 & 0.4337 \\
Turkey & 0.1215 & 0.1296 & 0.0003 & 0.2020 \\
Rest of world (ROW) & 0.0442 & 0.0615 & 0.0004 &
\end{tabular}

Source: Computed by the authors 
Table 3: Estimated parameters of the RSDAIDS with homogeneity, symmetry and block substitutability imposed

\begin{tabular}{|c|c|c|c|c|c|c|c|c|c|}
\hline \multicolumn{10}{|c|}{ Expenditure share } \\
\hline \multicolumn{6}{|c|}{ Beef } & \multicolumn{4}{|c|}{ Poultry } \\
\hline Parameter & $\mathrm{BR}$ & UAE & IRE & $\mathrm{NE}$ & ROW & $\mathrm{BR}$ & UAE & TUR & ROW \\
\hline \multicolumn{10}{|c|}{ Within the group } \\
\hline$\alpha_{i h}$ & $\begin{array}{c}1.9058^{* * *} \\
(6.9613)\end{array}$ & $\begin{array}{r}8.6478 * * * \\
(-1.9856)\end{array}$ & $\begin{array}{l}-0.1129 \\
(0.0193)\end{array}$ & $\begin{array}{c}0.4915 \\
(0.1735)\end{array}$ & $\begin{array}{c}-0.3856 \\
(-0.3077)\end{array}$ & $\begin{array}{c}0.0312 \\
(0.4210)\end{array}$ & $\begin{array}{c}0.0041 \\
(0.1230)\end{array}$ & $\begin{array}{c}-0.0640 \\
(-0.8759)\end{array}$ & $\begin{array}{c}0.0319 \\
(0.5610)\end{array}$ \\
\hline $\ln \left(P_{B B R}\right)$ & $\begin{array}{c}0.0194 \\
(1.1267)\end{array}$ & $\begin{array}{r}-0.0442 * * \\
(-3.6833)\end{array}$ & $\begin{array}{c}-.0775 \\
(-0.3744)\end{array}$ & $\begin{array}{c}-0.0312 * * * \\
(-2.600)\end{array}$ & $\begin{array}{c}0.1274 * * * \\
(5.6875)\end{array}$ & & & & \\
\hline $\ln \left(P_{B U A E}\right)$ & $\begin{array}{c}-0.0095 \\
(-1.1047)\end{array}$ & $\begin{array}{l}-0.00320 \\
(-0.5614)\end{array}$ & $\begin{array}{c}0.0126^{* *} \\
(1.2755)\end{array}$ & $\begin{array}{c}0.0167 * * * \\
(2.9298)\end{array}$ & $\begin{array}{c}0.0318 * * * \\
(2.9972)\end{array}$ & & & & \\
\hline $\ln \left(P_{B I R E}\right)$ & $\begin{array}{c}-0.0044 * * * \\
(-3.1429)\end{array}$ & $\begin{array}{l}-0.0007 \\
(-0.8000)\end{array}$ & $\begin{array}{l}0.0026^{*} \\
(1.5294)\end{array}$ & $\begin{array}{c}0.0019 * * \\
(1.9000)\end{array}$ & $\begin{array}{c}-0.0003 \\
(-0.1444)\end{array}$ & & & & \\
\hline $\ln \left(P_{B N E}\right)$ & $\begin{array}{c}0.0026 \\
(0.5652)\end{array}$ & $\begin{array}{l}-0.0059 * \\
(-1.5946)\end{array}$ & $\begin{array}{c}-0.0017 \\
(-0.2698)\end{array}$ & $\begin{array}{c}-0.0027 \\
(-0.8182)\end{array}$ & $\begin{array}{l}0.01073 * \\
(1.59702)\end{array}$ & & & & \\
\hline $\ln \left(P_{\text {BROW }}\right)$ & $\begin{array}{c}-0.02902 * * * \\
(-3.3721)\end{array}$ & $\begin{array}{c}-0.0054 \\
(-1.0189)\end{array}$ & $\begin{array}{c}0.0298 * * * \\
(3,2043)\end{array}$ & $\begin{array}{c}0.0228 * * * \\
(3.8814)\end{array}$ & $\begin{array}{c}-0.0036 \\
(-0.3600)\end{array}$ & & & & \\
\hline $\ln \left(P_{P U B R}\right)$ & & & & & & $\begin{array}{c}-0.0001 \\
(-0.2000)\end{array}$ & $\begin{array}{c}0.0021 * * * \\
(4.2000)\end{array}$ & $\begin{array}{c}-0.0008 \\
(-1.1429)\end{array}$ & $\begin{array}{c}-0.0001 \\
(-0.2000)\end{array}$ \\
\hline $\ln \left(P_{P U A E}\right)$ & & & & & & $\begin{array}{c}-0.0042 * * * \\
(10.5000)\end{array}$ & $\begin{array}{c}0.0108 * * * \\
(12.0000)\end{array}$ & $\begin{array}{c}-0.0125 * * * \\
(-10.4167)\end{array}$ & $\begin{array}{l}-0.0006 \\
(-0.4615)\end{array}$ \\
\hline $\begin{array}{l}\ln \left(P_{\text {PUTU }}\right) \\
\ln \left(P_{\text {PUROW }}\right)\end{array}$ & & & & & & $\begin{array}{c}-0.0064 * * * \\
(12.8000) \\
-0.0013 * * * \\
(-4.3333)\end{array}$ & $\begin{array}{c}0.0108 * * * \\
(-10.8000) \\
-0.0030 * * * \\
(4.1429)\end{array}$ & $\begin{array}{c}0.0014 \\
(1.0769) \\
0.0031 * * * \\
(3.8750)\end{array}$ & $\begin{array}{c}-0.0067 * * * \\
(-6.0909) \\
-0.0025^{* * *} \\
(-2.5000)\end{array}$ \\
\hline \multicolumn{10}{|l|}{ Between group } \\
\hline$P_{\text {Beef }}$ & & & & & & $\begin{array}{c}0.0326 * * * \\
(3.7045)\end{array}$ & $\begin{array}{c}0.0480 * * * \\
(2.9814)\end{array}$ & $\begin{array}{c}0.0175 \\
(1.1986)\end{array}$ & $\begin{array}{c}0.0096 \\
(0.0908)\end{array}$ \\
\hline$P_{\text {poultry }}$ & $\begin{array}{c}0.3689 * * * \\
(3.6309)\end{array}$ & $\begin{array}{c}0.0082 \\
(0.1514)\end{array}$ & $\begin{array}{c}0.0191^{*} \\
(1.60989)\end{array}$ & $\begin{array}{l}-0.0185^{*} \\
(-1.5072)\end{array}$ & $\begin{array}{c}0.0690 \\
(1.2105)\end{array}$ & & & & \\
\hline $\ln \left(\frac{E}{P}\right)$ & $\begin{array}{c}-0.1175 * * * \\
(-6.8314)\end{array}$ & $\begin{array}{c}0.5421 * * \\
(1.9795)\end{array}$ & $\begin{array}{c}0.0074 * * * \\
(6.1667)\end{array}$ & $\begin{array}{c}0.2737 * * * \\
(2.8273)\end{array}$ & $\begin{array}{c}-0.004 * * * \\
(-8.0000)\end{array}$ & $\begin{array}{c}0.0030 * * * \\
(2.5000)\end{array}$ & $\begin{array}{c}0.0010 \\
(0.1000)\end{array}$ & $\begin{array}{c}0.0012 * * * \\
(12.000)\end{array}$ & $\begin{array}{c}0.0003 \\
(0.1000)\end{array}$ \\
\hline Dummy $_{\text {Beef }}$ & $\begin{array}{c}-0.0135 * * \\
(-9.000)\end{array}$ & $\begin{array}{c}0.0018 \\
(1.0271)\end{array}$ & $\begin{array}{c}0.0010 * * * \\
(-4.5000)\end{array}$ & $\begin{array}{c}0.0311 * * * \\
(4.7619)\end{array}$ & $\begin{array}{l}-0.0004 * * \\
(-8.6957)\end{array}$ & & & & \\
\hline Dummy $_{\text {poultry }}$ & & & & & & $\begin{array}{l}-0.0020 * \\
(-1.5037)\end{array}$ & $\begin{array}{l}-0.0013 \\
(-0.753)\end{array}$ & $\begin{array}{c}0.0124 * * * \\
(-5.9048)\end{array}$ & $\begin{array}{c}-0.0026 * * * \\
(23.7273)\end{array}$ \\
\hline RMSE & 0.7087 & 0.8959 & 0.8145 & 0.3769 & 0.7095 & 0.6363 & 0.9408 & 0.9852 & 0.8690 \\
\hline
\end{tabular}

BR: Brazil, UAE: United Arab Emirates, IRE: Ireland, NE: Netherlands, TUR: Turkey and ROW: Rest of World

$*$, ** and $* * *$ : Significant at 10, 5 and $1 \%$ level of significance, respectively; t-ratios are reported in parentheses

Table 4 presents the results of goodness-of-fit analysis. McElroy's $\mathrm{R}^{2}$ was used as a measure of goodness of fit for the system. Based on the majority of the estimated equations contain a number of statistically significant coefficients, and overall the model fits the data well. Most of the McElroy's $\mathrm{R}^{2}$ values are reasonable except for the value for the Netherlands beef share equation from the RSDAIDS, which is of low magnitude. It might be that either data are limited or the Netherlands beef accounts for a small percentage of the total expenditure. For beef, the significant estimates concern the demand functions for Brazil, United Arab Emirates and ROW, and also for poultry demand functions consist of United Arab Emirates and Turkey. The beef own price coefficient estimate for all countries (except Ireland) is not significant. The positive own price coefficient of Ireland which contradicts the downward own-price-demand curve theory, indicating that beef imported from Ireland could be a Giffen good in the Iran market. However, in the real market, beef is not a Giffen good and the reason for that contradictory finding could be data limitation or correlation.

Table 4. Results of product block separability for the RSDAIDS model

\begin{tabular}{llll}
\hline Type of Test & Null Hypothesis & F-test & P-value \\
\hline Block Separability & Beef is separable from Poultry & 81.3651 & 0.0001 \\
\hline Source: Computed by the authors &
\end{tabular}

For beef, the significant estimates concern the demand functions for almost all countries are considered. The expenditure for Brazil beef is negatively and significantly correlated with Ireland price (-0.0044) 
and rest of world (-0.02902). Considering that Brazil is one of the largest exporters of meat in the world market and represents competition of Brazil with the other meat suppliers. The United Arab Emirates beef is having statistically significant relation with Brazil prices, which is negative $(-0.0442)$. This demonstrates that at this ever-increasing phase of Iran import demand; consumer utility also rises with source differentiation. The positive cross-relations among price and expenditure for Netherlands with United Arab Emirates, Ireland and Rest of World confirm that price competition strategies on the supply side and source differentiation strategies on the demand side are implemented for this undifferentiated product.

For the poultry share equation, only ROW coefficients are significant at the lower level and have a negative sign while the United Arab Emirates own-price coefficients are positive and significant which is not consistent with the downward own-price-demand curve theory. This theory also indicates that poultry import from United Arab Emirate could be a Giffen good in the Iran market. Therefore, it can be justified that Iran is relatively self-sufficient in poultry. The Iranian consumers prefer fresh domestic poultry in comparison to imported frozen poultry.

It was observed that cross-relations between prices and expenditure for Brazil with the United Arab Emirates, and United Arab Emirates with Turkey/rest of world (ROW) were negative and significant but differences were small to the fourth decimal digit in magnitude. Considering the relation between meat group, only Brazilian beef as well as Emirate poultry and beef display significant coefficients at $1 \%$. Also beef and poultry seem to have a substitution relationship. The dummy variables measuring the effects of Disease Indicator reflecting BSE, FMD and Avian Influenza (Flu) outbreaks related exporter countries. The BSE and FDM dummy variable of beef for Brazilian, Ireland, Netherlands and Rest of World were significant and negative and Avian Influenza (Flu) of Turkey and Rest of World was significant at the lower level. In the beef market, the estimates showed a small decrease in the shares of beef from all sources (except United Arab Emirates) during 2002-16. The same result was true for avian influenza in Brazil, Turkey and other countries. Table 4 shows the results for block separability. The null hypothesis that the beef import demand can be estimated separately for poultry was rejected as well at $1 \%$ level of significance.

The relation of the Lin and Levin test in this research was based on three types of non-dimensional and non-proximal relationships, with the width of the source and without the trend, with the width of the source and with the process, which at best indicated the results (Table 5). Table 6 shows the results of the random effects test using the likelihood test. The data presented in Table 6 show that except budget share of poultry from Brazil, they confirmed the random effect.

Table 5. Levin-Lin-Chu unit-root test

\begin{tabular}{|c|c|c|c|c|c|c|c|c|}
\hline \multirow[t]{2}{*}{ Variable } & \multicolumn{2}{|c|}{ W } & \multicolumn{2}{|c|}{$\mathrm{LnP}$} & \multicolumn{2}{|c|}{$\mathrm{LnP}_{\mathrm{j}}$} & \multicolumn{2}{|c|}{$\operatorname{Ln}\left(\mathrm{E} / \mathrm{P}^{*}\right)$} \\
\hline & Statistic & $p$-value & Statistic & p-value & Statistic & $\mathrm{p}$-value & Statistic & p-value \\
\hline Include time trend & -19.7929 & 0.0000 & -6.6343 & 0.0000 & -6.8728 & 0.0000 & -6.1859 & 0.0000 \\
\hline $\begin{array}{l}\text { Subtract cross- } \\
\text { sectional means }\end{array}$ & -13.6158 & 0.0000 & -5.2379 & 0.0000 & -1.4403 & 0.0749 & 4.0419 & 1.0000 \\
\hline $\begin{array}{l}\text { suppress panel } \\
\text { specific means }\end{array}$ & -3.6412 & 0.0001 & -2.5571 & 0.0053 & -2.1110 & 0.0174 & -2.7437 & 0.0030 \\
\hline
\end{tabular}

Table 6. Random effects test result

\begin{tabular}{cllcll}
\hline Variable & Likelihood test & $\mathrm{p}$-value & Variable & Likelihood test & $\mathrm{p}$-value \\
\hline$W_{B B R}$ & 19.45 & 0.0126 & $W_{P U B R}$ & 8.43 & 0.2963 \\
$W_{B U A E}$ & 35.80 & 0.0000 & $W_{P U A E}$ & 13.24 & 0.0464 \\
$W_{B I R E}$ & 28.79 & 0.0003 & $W_{P U T U}$ & 26.52 & 0.0004 \\
$W_{B N E}$ & 26.36 & 0.0009 & $W_{P U R O W}$ & 18.42 & 0.0102 \\
$W_{B R O W}$ & 22.28 & 0.0044 & & & \\
\hline
\end{tabular}

Source: Computed by the authors

\section{Elasticity estimates}

Marshallian elasticity and expenditure elasticity estimates

Table 7 presents the Marshallian (uncompensated) elasticities. Consistent with what is expected from economic theory, all of own-price elasticities for beef and poultry were statistically significant. The own price elasticities 
of Brazil, United Arab Emirates and Ireland were lower than one indicating inelastic demand. The magnitudes of response to these countries suggest that beef consumers would not probably replace the imported beef with other substitutes when faced with higher import prices. The low sensitivity of these countries, in both poultry and beef markets, there can be several reasons, including differences in quality, shipping costs or access to the product market. This finding is consistent with market characteristics fragmentation of market shares, product homogeneity and volatility of commercial strategies.

Table 7. Marshalian Elasticity's (uncompensated Elasticity's) for of Iran Meat Import Demand using Restricted Source Differentiated AIDS (Columns are prices)

\begin{tabular}{|c|c|c|c|c|c|c|c|c|c|}
\hline Parameter & BR & UAE & IRE & $\mathrm{NE}$ & ROW & BR & UAE & TUR & ROW \\
\hline \multicolumn{10}{|l|}{ Beef } \\
\hline BR & $\begin{array}{r}-0.8375^{* * *} \\
(-4.7933)\end{array}$ & $\begin{array}{r}-0.0246 * * \\
(-2.2574)\end{array}$ & $\begin{array}{r}-0.1685^{* *} \\
(-2.3114)\end{array}$ & $\begin{array}{r}-0.0550 \\
(-0.1695)\end{array}$ & $\begin{array}{r}0.3443 * * * \\
(-2.4032)\end{array}$ & & & & \\
\hline UA & $\begin{array}{c}-0.8498 * * * \\
(-10.489)\end{array}$ & $\begin{array}{r}-0.9532 * * * \\
(-4.1180)\end{array}$ & $\begin{array}{r}-0.0358 * * * \\
(-5.5426)\end{array}$ & $\begin{array}{l}-0.0625 \\
(-1.272)\end{array}$ & $\begin{array}{l}-0.2257 * * * \\
(-1.6158)\end{array}$ & & & & \\
\hline IR & $\begin{array}{c}-0.181 * * * \\
(-16.7100)\end{array}$ & $\begin{array}{r}-0.0676^{* * *} \\
(-3.4133)\end{array}$ & $\begin{array}{r}-0.9454 * * * \\
(-9.8595)\end{array}$ & $\begin{array}{l}0.0341 * * * \\
(-2.8549)\end{array}$ & $\begin{array}{r}-0.0376 * * * \\
(-2.6239)\end{array}$ & & & & \\
\hline NE & $\begin{array}{c}0.2507 * * * \\
(-20.479)\end{array}$ & $\begin{array}{c}0.0469 * * * \\
(-5.9091)\end{array}$ & $\begin{array}{c}-0.0062 * * * \\
(-12.418)\end{array}$ & $\begin{array}{c}-1.0112 * * * \\
(-4.7123)\end{array}$ & $\begin{array}{c}0.2543 * * * \\
(-4.077)\end{array}$ & & & & \\
\hline ROW & $\begin{array}{r}-0.1535 \\
(-0.8634)\end{array}$ & $\begin{array}{r}-0.024 * * * \\
(-8.0699)\end{array}$ & $\begin{array}{c}0.1686^{* * *} \\
(-16.882)\end{array}$ & $\begin{array}{l}0.1303^{* * *} \\
(-11.678)\end{array}$ & $\begin{array}{l}-1.0163 * * * \\
(-22.7172)\end{array}$ & & & & \\
\hline \multicolumn{10}{|l|}{ Poultry } \\
\hline $\mathrm{BR}$ & & & & & & $\begin{array}{c}-0.9801 * * * \\
(-4.3058)\end{array}$ & $\begin{array}{c}-0.0245^{* * *} \\
(-3.4751)\end{array}$ & $\begin{array}{l}-0.0100 * * * \\
(-21.9061)\end{array}$ & $\begin{aligned} &-0.0013 \\
&(-1.1747)\end{aligned}$ \\
\hline UAE & & & & & & $\begin{array}{l}-0.0249 * * * \\
(-4.0077)\end{array}$ & $\begin{array}{l}-0.9362 * * * \\
(-8.8285)\end{array}$ & $\begin{array}{c}-0.0744 \\
(-0.789)\end{array}$ & $\begin{array}{l}-0.0036^{* *} \\
(-11.789)\end{array}$ \\
\hline TUR & & & & & & $\begin{array}{l}-0.0098 * * \\
(-1.8328)\end{array}$ & $\begin{array}{r}-0.0167 * * * \\
(-4.1292)\end{array}$ & $\begin{array}{c}-0.9991 * * * \\
(-4.6440)\end{array}$ & $\begin{array}{c}-0.0103 * * * \\
(-6.3773)\end{array}$ \\
\hline ROW & & & & & & $\begin{array}{r}-0.0155^{*} \\
(-1.621)\end{array}$ & $\begin{array}{l}-0.0346 * * * \\
(-15.784)\end{array}$ & $\begin{array}{r}0.0369 \\
(-7.0132)\end{array}$ & $\begin{array}{l}-1.0298^{* *} \\
(-2.18719)\end{array}$ \\
\hline Beef & & & & & & $\begin{array}{r}0.3763 * * * \\
(-3.7059)\end{array}$ & $\begin{array}{r}0.2838 * * * \\
(-2.8132)\end{array}$ & $\begin{array}{r}0.0253 * * * \\
(-6.8667)\end{array}$ & $\begin{array}{r}0.1144 * * * \\
(-4.5961)\end{array}$ \\
\hline Poultry & $\begin{array}{l}0.0111 * * * \\
(-2.6792)\end{array}$ & $\begin{array}{r}-0.6439 * * * \\
(-3.8234)\end{array}$ & $\begin{array}{r}-0.5182 * * * \\
(-4.3056)\end{array}$ & $\begin{array}{r}-0.117 * * * \\
(-2.7933)\end{array}$ & $\begin{array}{r}0.3963 * * * \\
(-2.4418)\end{array}$ & & & & \\
\hline Expenditure & $\begin{array}{r}1.7271 * * * \\
(3.9549)\end{array}$ & $\begin{array}{r}2.8959 * * * \\
(3.7560)\end{array}$ & $\begin{array}{r}1.1765 * * * \\
(5.6383) \\
\end{array}$ & $\begin{array}{r}0.5126 * * * \\
(3.1716) \\
\end{array}$ & $\begin{array}{r}0.9775 * * * \\
(5.0589) \\
\end{array}$ & $\begin{array}{r}1.0012 * * * \\
(4.0254)\end{array}$ & $\begin{array}{r}1.1006 * * * \\
(5.9773)\end{array}$ & $\begin{array}{r}1.0018^{* * *} \\
(3.5654)\end{array}$ & $\begin{array}{r}0.7001 * * * \\
(4.9791)\end{array}$ \\
\hline
\end{tabular}

BR: Brazil, UAE: United Arab Emirates, IRE: Ireland, NE: Netherlands, TUR: Turkey

$*, * *$ and $* * *$ : Significant at 10,5 and $1 \%$ levels of significance, respectively. t-ratios are reported in parentheses

While beef from Netherlands and ROW, own-price elasticities are greater than one $(-1.0112$ and 1.01631, respectively). This suggests that as the price of export beef increases by $10 \%$, the domestic demand of imported beef coming from Netherlands and ROW will decrease by 10.11 and $10.16 \%$, respectively. So, beef from Netherlands and ROW suffers from the competition of other suppliers, and its demand is sensitive to price policies. In the poultry market, Brazil and ROW price elasticities are elastic.

In the beef and poultry market, expenditure elasticities of Brazil, United Arab Emirates, Ireland and Turkey are significant and larger than one. This indicates that meat from these countries can be considered as luxury (better quality) commodities, while the expenditure elasticity of beef and chicken meat imported from ROW as well as beef imported from the Netherlands is significant and lower than one. So, the share of Brazil, United Arab Emirates, Ireland and Turkey meat increases faster than the share of Netherlands and ROW.

The expenditure elasticity are greater than 1 (for beef from Brazil, United Arab Emirates and Ireland and poultry from Brazil, United Arab Emirates and Turkey) implying that there is a tendency for these countries imports to be particularly favoured over other imports when total expenditure on beef/poultry imports grows between main exporters of beef/poultry to Iran or slightly lower than 1 (for beef from Netherlands and ROW, and poultry from ROW), suggesting that expanded beef import expenditures result in a less than proportionate increase from Netherlands and ROW. Over the time, this would seem to suggest a longer-term decline in market share from these sources, holding relative prices constant. Therefore, expenditure elasticity confirms the income determinant in the purchase of imported beef and poultry. Iranian meat consumption is moving towards new suppliers and product differentiation, and the emerging scenario is competitive. 
According to Yang and Koo (1994), a country is regarded as having strong export potential in an import market if demand for its product is price inelastic but expenditure elastic. Brazil, United Arab Emirates, Ireland and Turkey satisfy these criteria in the beef and poultry markets. On the contrary, Netherlands and ROW appear to be at a competitive disadvantage in the beef and poultry market due to price elastic and expenditure inelastic demand for its product and, this could explain why Netherlands and ROW's export of the product declined over time while Brazil and United Arab Emirates exhibited increasing or stable export to Iran. Porter (1985) defines competitive advantage as an advantage over competitors achieved by offering consumers a greater value, either through lower prices or by providing greater benefits that justify higher prices.

The cross price elasticities are conditional on total expenditure of meat imported by the country and account for both substitution and expenditure effects of price changes. The cross-price effect varied for most of the imported beef and poultry.

The positive cross price elasticities suggest some degree of substitution between imports from various sources, while negative cross price elasticities suggest that the expenditure effect of price changes outweighs the pure substitution effects. Regarding the beef and poultry market, more than half of cross elasticities were negative, small and statistically significant for most exporting countries indicating complementary relationships between imported beef/poultry from different sources, showing no fierce competition among these countries, while the relation between Brazil vs. ROW, Ireland vs. Netherlands, Netherlands vs. Brazil/United Arab Emirates/ROW, ROW vs. Ireland/Netherlands and ROW vs. Turkey and indicating substitution relationships.

The complementary relationships between beef and poultry are more difficult to explain. These peculiar effects were also found in domestic demands (Hayes et al., 1990) and are not unusual in demand studies. Several restrictions imposed on the data (e.g. adding-up, homogeneity and symmetry) may account for the apparent complementary relationships (Yang and Koo, 1994). Pitts and Herlihy (1982) showed evidence supporting the fixed expenditure hypothesis. The hypothesis says that when the prices of two products differ substantially and the own price elasticity of a product is less than one, a decrease in the price may increase the consumption of both the products, with a relatively fixed expenditure on the group. Also, the lack of competitiveness between imported meat is due to co-movements of exchange rates so that a factor since the value was used as a proxy for price and the role of exchange rates may not be rejected, or due to the difference in the quality or differences in meat cuts and products between exporter countries or model restrictions.

Table 8: Hicksian Elasticity's (compensated Elasticity's) for of Iran Meat Import Demand using Restricted Source Differentiated AIDS (Columns are prices)

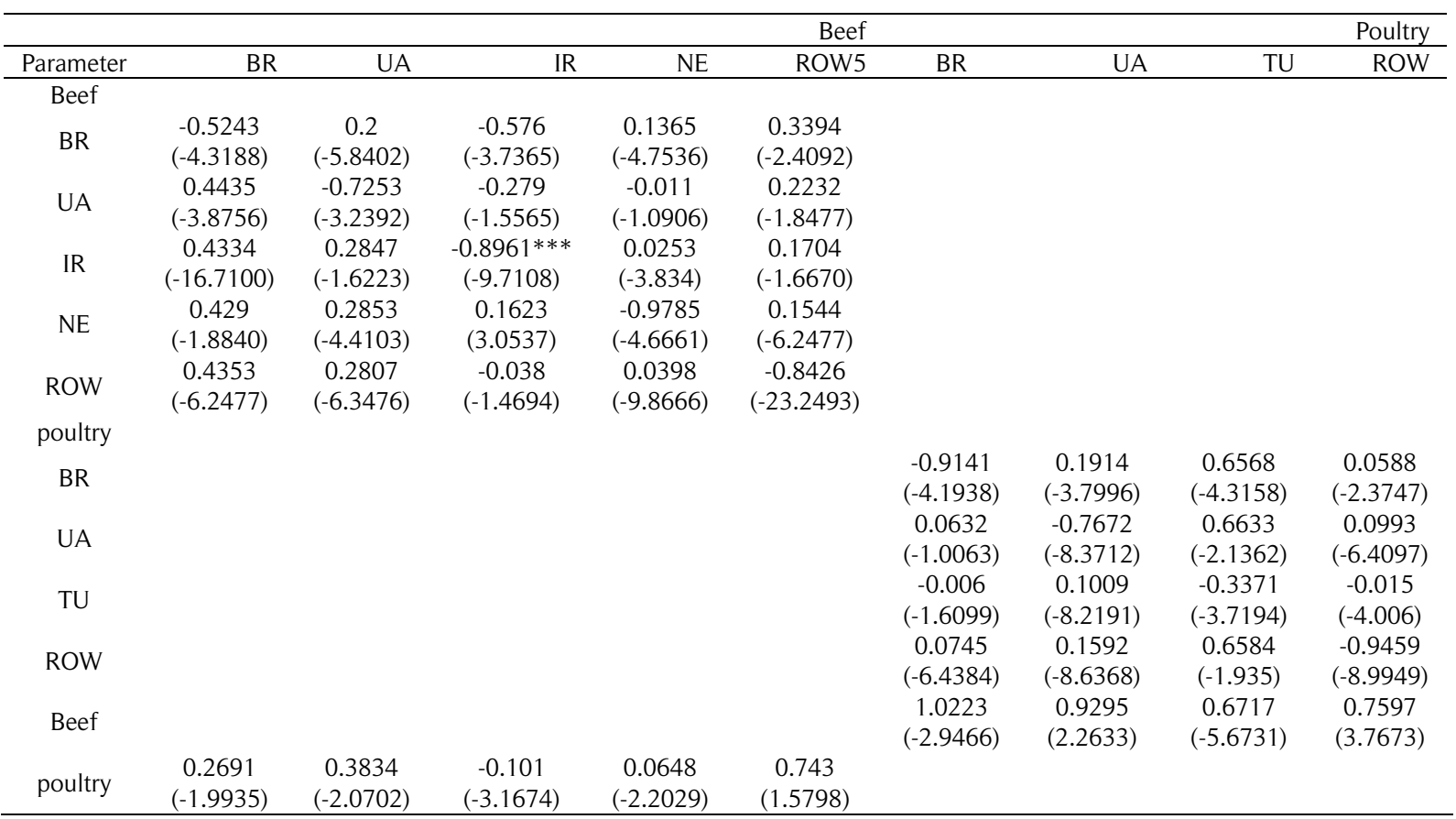

BR: Brazil, UAE: United Arab Emirates, IRE: Ireland, NE : Netherlands, TUR :Turkey.

$*, * *$ and $* * *$ : Significant at $10 \%, 5 \%$ and $1 \%$ level of significance, respectively, t-ratios are reported in parentheses. 


\section{Hicksian elasticities}

To better understand the competition relationship among suppliers, the Hicksian cross price elasticities are calculated and reported in Table 8. A positive price elasticity between imported beef and poultry from two countries denotes substitutes and a negative value denotes complements. In total, there are 50 pairs of cross price elasticities among the nine countries. For each pair, the sign and significance and magnitude may differ. In general, most pairs of Hicksian cross-price elasticities at the higher triangle of the panel are significant. Twenty-seven of them are positive and indicate substitutes. In both the markets, four pairs of cross-price elasticities are negative, significant and indicate complements.

\section{Conclusion}

This study estimated the impacts of economic factors (meat prices and expenditures) and non-economic factors (animal diseases/outbreaks) on the import demand for source differentiated meat during 2002-16 in Iran. In fact, this study has examined the factors driving the competitive relations among suppliers and products for the Iranian beef and poultry import market.

Results of this study shed light on Iran consumer preferences with regard to imported meat. This is the first study that analyzes the Iran meat demand differentiated by source. The estimation results show that Brazil, United Arab Emirates and Ireland have a competitive advantage compared with the Netherlands and ROW (Australia, Belgium, India and Germany). For poultry, Turkey and the United Arab Emirates also have the competitive advantage compared with other sources (Brazil and ROW). This is determined by the Brazil, United Arab Emirates, Ireland and Turkey's relatively low own-price elasticity and high expenditure elasticity, compared with rest two sources for beef and poultry and considering the future growth in Iran consumer's per capita income. Therefore, the growing per capita income in Iran is expected to expand the marketing potential for Brazil, United Arab Emirates and Ireland for beef, and United Arab Emirates and Turkey for poultry exporters. These countries have the most gain from an increase in the size of imported meat market in terms of their beef and poultry exports.

It is evident that the patterns used in Iran's trade for different countries are different. However, aggregation over sources may demonstrate considerable bias for estimating the elasticities when evaluating demand models, which especially when meat with a considerable market share of importers such as beef are highlighted. Although the findings are rather reasonable, it is worth noting that the estimated elasticities can be influenced by the poor quality of data, the nature of aggregations based on the source and by inaccurate dynamic specification related to the model. In addition, there is a scope for conducting other studies in this area.

All suppliers are searching for more opportunities for development in this developing market although their strength of competition is different and the relations are often regarded as asymmetric. Thus, entrepreneurs and managers focus on presenting new methods and strength for new investments.

\section{References}

Andayani, S. R. M. and Tilley, D. S. (1997). Demand and competition among supply sources: The Indonesian fruit import market. Journal of Agricultural and Applied Economics, 29:279-289.

Anonymous (2017). Deputy Director of Planning and Economic Affairs of the Ministry of Agriculture of the Islamic Republic of Iran, http://www.maj.ir

Boumahdi, R., Chaaban, J. and Thomas, A. (2004). Import Demand Estimation with Country and Products Effects: Application of Multi-way Unbalanced Panel Data Models to Libanese Imports. Institut National de la Recherche Agronomique, $3^{\text {rd }}$ Ed., 3: 35-40

Breusch, T. S. and Pagan, A. R. (1980). The lagrange multiplier test and its applications to model specification in econometrics. Review of Economic Studies, 47: 239-253.

Capitello, R., Agnoli, L. and Begalli, D. (2015). Chinese import demand for wine: evidence from econometric estimations. Journal of Wine Research, 26:115-135.

Cheng, Ya Hao, Zhifeng, Gao and Seale, J. (2015). Changing Structure of China's Meat Imports. Journal of Integrative Agriculture, 14: 1081-91. 
Chern, W. S., Ishibashi, K., Taniguchi, K., Tokoyama, Y. and Pingali, P. (2003). Analysis of the food consumption of Japanese households. Food and Agriculture Organization of the United Nations, Rome

Deaton, A., and Muellbauer, J. (1980). An almost ideal demand system. American Economic Review, 70: 312 326.

Eales, J. S. and Unnevehr, L. J. (1988). Demand for beef and chicken products: separability and structural change. American Journal of Agricultural Economics, 70: 521-532.

Giorgioni, G. and Holden, K. (2003). Does the Ricardian equivalence proposition hold in less developed countries? International Review of Applied Economics, 17 :209-221.

Gómez, A., Jiménez. J. G. P. and Figueroa, G. F. (2015). Contribution of the Nafta countries in the Japanese Pork market. Journal Agraria,12:117-125

Green, R. and Alston, J. M. (1990. Elasticities in AIDS models. American Journal of Agricultural Economics, 72: 442-45.

Hausman, J. A. and Taylor, W. E. (1981). Panel Data and Unobservable Individual Effects. Econometrica, 49 :1377-1398.

Hayes, D. J., Wahl, T. I. and Williams, G. W. (1990). Testing Restrictions on a Model of Japanese Meat Demand. American Journal of Agricultural Economics, 72: 556-566.

Henneberry, S. R, and Seong-huyk, H. (2007). Meat Demand in South Korea: An Application of Restricted Source-Differentiated Almost Ideal Demand System Model”. Journal of Agricultural and Resource Economics, 39:47-60.

Levin, A., Chien-Fu, L., Chu, J. and Chia-Shang (2002). Unit root tests in panel data: asymptotic and finitesample properties. Journal of Econometrics, Elsevier, 108: 1-24.

Mekonnen, D. K., Fonsah., E. G. and Borgotti, B. (2011). US import demand for apple: source differentiated almost ideal demand system approach. International journal of Trade and Global Markets, 4: 372382 .

Moschini, G. (1995). Units of Measurement And The Stone Index In Demand System Estimation. American Journal of Agricultural Economics, 77: 63-68.

Parizan, V. and Esmaeili, A. (2008). Assessing Import Demand Factors of Livestock Products in Iran. Agricultural Economics, 2: 2008-5524 (in Persian).

Pitts, E., and Herlihy, P. (1982). Perverse substitution relationships in demand studies: the example of butter and margarine. Journal of Agriculture Economics., 33:37-46.

Porter, M. E. (1985). Competitive Advantage. Creating and sustaining superior performance. Macmillan Inc. London .

Sun, L. and Niquidet, K. (2017). Elasticity of import demand for wood pellets by the European Union. Forest Policy and Economics, 81: 83-87.

Thanagopal, T. and Félix, H. (2014). A restricted source differentiated almost ideal demand system, augmented with quality in the study of French imports", Working Paper, No. 698, San Rafael, CA: Forum for Research and International Trade, http://www.freit.org/WorkingPapers/Papers/TradePolicyGeneral/FREIT698.pdf (accessed January 20, 2013).

Yang, S., and Koo, W. W. (1994). Japanese meat import demand estimation with the source differentiated AIDS models. Journal of Agricultural and Resource Economics 19: 396-408. 